\section{Universitetet i Oslo}

www.med.uio.no/disputaser/

Morten Andreas Horn, ph.d. X-linked adrenoleukodystrophy in Norway: clinical and epidemiological aspects. Utgår fra Institutt for klinisk medisin. Disputas 21.1. 2016.

Bedømmelseskomité: Charalampos Tzoulis, Nevrologisk avdeling, Haukeland universitetssykehus, Benedicte Paus, Avdeling for medisinsk genetikk, Oslo universitetssykehus, og Christoffer Lundqvist, Klinikk for helsetjenesteforskning og psykiatri, Akershus universitetssykehus, Lørenskog.

Veiledere: Chantal M.E. Tallaksen og Ola H Skjeldal.

\section{Universitetet i Bergen www.uib.no/info/dr_grad/}

Siren Irene Rettedal, ph.d. Extended-spectrum beta-lactamase producing. Enterobacteriaceae in neonates; hospital outbreak, colonization, transmission and persistence. Utgår fra Klinisk institutt 2. Disputas 15.1. 2016.

Bedømmelseskomité: Colm O’Donnell, University College, Dublin, Irland, Claus Klingenberg, Universitetet i Troms $\emptyset$, og Harleen Grewal, Universitetet i Bergen.

Veiledere: Knut Øymar og Arnfinn Sundsfjord.

Eirunn Waatevik Saure, ph.d. Predictors of arterial blood gases in COPD patients. Utgår fra Klinisk institutt 2. Disputas 21.1. 2016. Bedømmelseskomité: Magnus Sköld, Karolinska Institutet, Sverige, Malcolm Sue-Chu, Norges teknisk-naturvitenskapelige universitet, og Rebecca Cox, Universitetet i Bergen. Veiledere: Jon Hardie, Per Bakke og Tomas Eagan.
Jintana Bunpan Andersen, ph.d. Epidemiology, comorbidity and clinical course of myasthenia gravis. A registry-based study. Utgår fra Klinisk institutt 1. Disputas 22.1. 2016.

Bedømmelseskomité: David Gaist, Syddansk Universitet, Danmark, Natalya Tcinzerling, North-Western State Medical University named after I.I. Mechnikov, St. Petersburg, Russland, og Rune Kroken, Universitetet i Bergen.

Veiledere: Nils Erik Gilhus, Jone Furlund Owe og Anders Engeland.

Ognjen Bojovic, ph.d. Spinal sensitization and expression of immediate early genes. Prolonged opioid treatment and neuropathic nociception. Utgår fra Institutt for biomedisin. Disputas 22.1. 2016.

Bedømmelseskomité: Johannes Gjerstad, Universitetet i Oslo, Odd-Geir Berge, OGB Consulting, Sverige, og Lars Bø, Universitetet i Bergen.

Veiledere: Arne Tjølsen og Clive Bramham.

\section{Universitetet i Troms $\emptyset$ Norges arktiske universitet https://uit.no/tavla}

Audhild Nyrnes, ph.d. Atrial fibrillation in The Tromsø Study 1994-2007. Risk factors, occurrence and gender differences. Utgår fra Institutt for samfunnsmedisin. Disputas 14.1. 2016.

Bedømmelseskomité: Annika Rosengren, Sahlgrenska Universitetssjukhuset, Östra Hospital, Sverige, Jan Pål Loennechen,

Institutt for sirkula, og Truls Myrmel, Institutt for klinisk medisin, Det helsevitenskapelige fakultet, Universitetet i Troms $\emptyset$ - Norges arktiske universitet.

Veiledere: Maja-Lisa Løchen, Inger Njølstad og Ellisiv B. Mathiesen.

\title{
St. Olavs Orden til Jan Svennevig
}

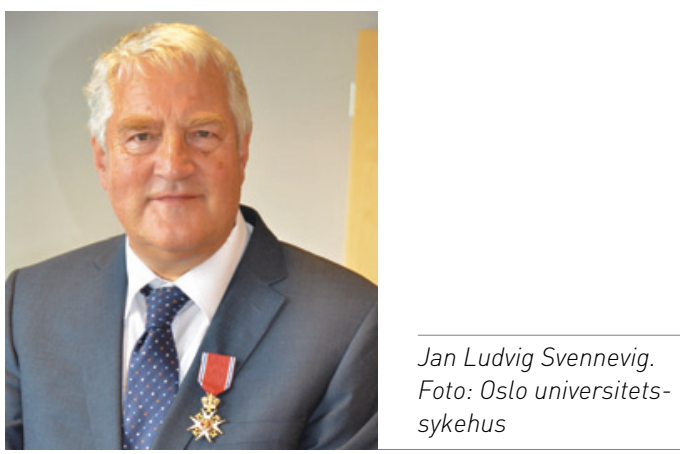

Jan Ludvig Svennevig (f. 1943), professor emeritus ved Universitetet i Oslo, er utnevnt til ridder 1. klasse av St. Olavs Orden for sin mangeårige innsats innen hjertemedisin.

Svennevig tok medisinsk embetseksamen i Heidelberg i Tyskland i 1967. Han har doktorgrader både fra Universitetet i Heidelberg 1967 og Universitetet i Oslo 1982. Han ble godkjent spesialist i generell kirurgi i 1978, i thoraxkirurgi i 1983 og i karkirurgi i 1986.
Etter turnustjeneste ved Drammen sykehus og i Kvinesdal kommune, tok Svennevig sin kirurgiske utdanning ved sykehusene i Farsund, Arendal og ved Ullevål sykehus og Rikshospitalet. Han var ansatt som overlege i hjerte-lunge-karkirurgi ved Ullevål sykehus fra 1984 til 1989, og som overlege og senere avdelingssjef ved Rikshospitalet fra 1989. I 1989 ble han også professor i hjertekirurgi ved Universitetet i Oslo.

Svennevig har publisert over 200 vitenskapelige artikler og en del fagbøker. Han har veiledet en rekke doktorgradsstudenter og vært gjesteforeleser ved flere utenlandske universiteter.

Fra 1995 til 1999 var Svennevig leder for Hjerte- og karrådet, og fra 2002 til 2005 var han leder for Nasjonalforeningen for folkehelsen.

Jan Ludvig Svennevig er æresmedlem av Norsk kirurgisk forening, og etter at han ble pensjonert i 2010 har Svennevig fortsatt å arbeide med medisinske kvalitetsregistre.

\section{Gunn Marit Seberg}

Tidsskriftet 